\title{
THE MEDIEVAL MANOR
}

An institutional and topographical analysis

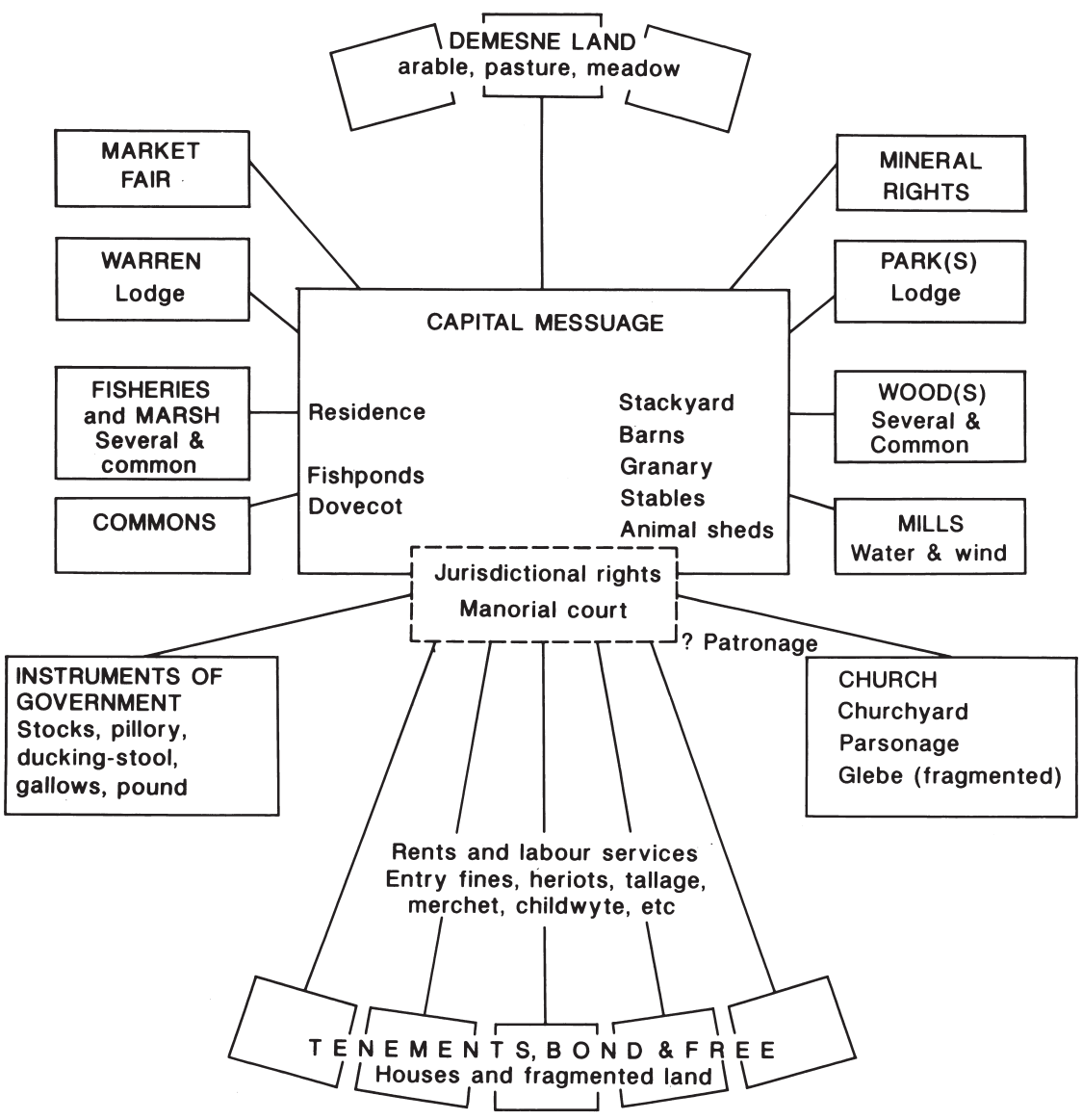

with acknowledgements to David Dymond

Figure 1 